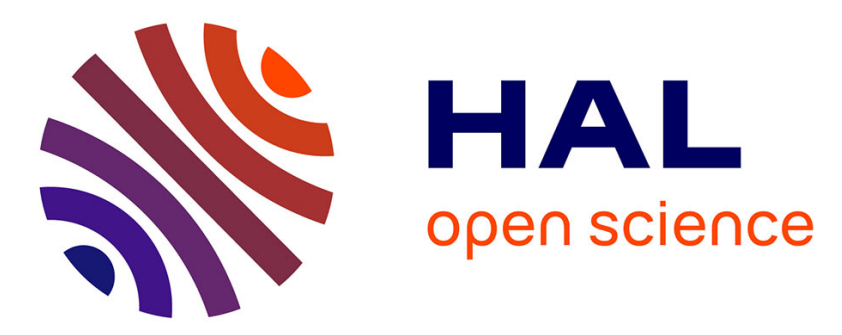

\title{
Factors influencing prokaryotes in an intertidal mudflat and the resulting depth gradients
}

Céline Lavergne, Hélène Agogué, Aude Leynaert, Mélanie Raimonet, Rutger de Wit, Philippe Pineau, Martine Bréret, Nicolas Lachaussée, Christine Dupuy

\section{To cite this version:}

Céline Lavergne, Hélène Agogué, Aude Leynaert, Mélanie Raimonet, Rutger de Wit, et al.. Factors influencing prokaryotes in an intertidal mudflat and the resulting depth gradients. Estuarine, Coastal and Shelf Science, 2017, 189, pp.74 - 83. 10.1016/j.ecss.2017.03.008 . hal-01491829

\section{HAL Id: hal-01491829 \\ https://hal.science/hal-01491829}

Submitted on 17 Mar 2017

HAL is a multi-disciplinary open access archive for the deposit and dissemination of scientific research documents, whether they are published or not. The documents may come from teaching and research institutions in France or abroad, or from public or private research centers.
L'archive ouverte pluridisciplinaire HAL, est destinée au dépôt et à la diffusion de documents scientifiques de niveau recherche, publiés ou non, émanant des établissements d'enseignement et de recherche français ou étrangers, des laboratoires publics ou privés. 


\section{$1 \quad$ Factors influencing prokaryotes in an intertidal mudflat}

\section{and the resulting depth gradients}

Céline Lavergne $*^{1,4}$, Hélène Agogué ${ }^{1}$, Aude Leynaert ${ }^{2}$, Mélanie Raimonet ${ }^{2}$, Rutger

5 De Wit ${ }^{3}$, Philippe Pineau ${ }^{1}$, Martine Bréret ${ }^{1}$, Nicolas Lachaussée ${ }^{1}$, Christine Dupuy ${ }^{1}$

6

$7 \quad{ }^{1}$ LIENSs, UMR 7266 Université de la Rochelle, CNRS. 2 rue Olympe de Gouges, 17000 La

8 Rochelle, France

$9 \quad{ }^{2}$ LEMAR, UMR 6539 Université de Bretagne Occidentale, CNRS, IRD, Ifremer. Institut

10 Universitaire Européen de la Mer, 29280 Plouzané, France

$11{ }^{3}$ Center for Marine Biodiversity, Exploitation and Conservation (MARBEC). Université de

12 Montpellier, CNRS, IRD, Ifremer. Place Eugène Bataillon, Case 093, F-34095 Montpellier

13 Cedex 5, France

$14{ }^{4}$ School of Biochemical Engineering, Pontificia Universidad Católica de Valparaíso, Avenida

15 Brasil 2085, Valparaíso, Chile

16 *Corresponding author: Céline Lavergne, School of Biochemical Engineering,

17 Pontificia Universidad Católica de Valparaíso, Avenida Brasil 2085, Valparaíso, Chile

18 e-mail: lavergne.celine@gmail.com

19

20 Running title: Prokaryote drivers in mudflats 
 \\ 1 Highlights}

- Strong stratification in two horizons of microbial densities and activities in the first $10 \mathrm{~cm}$ of the sediment.

- A gradual transition could correspond to an environmental ecocline rather than an ecotone.

- Bottom-up-control of the prokaryotic community revealed by the variation partitioning analysis.

\section{Abstract}

Intertidal mudflats are rich and fluctuating systems. The upper $20 \mathrm{~cm}$ support a high diversity and density of microorganisms that ensure diversified roles. The depth profiles of microbial abundances and activities were measured in an intertidal mudflat (Marennes-Oléron Bay, SW France) at centimeter-scale resolution $(0-10 \mathrm{~cm}$ below the sediment surface). The aim of the study was to detect microbial stratification patterns within the sediments and how this stratification is shaped by environmental drivers. Two sampling dates, i.e. one in summer and another in winter, were compared. The highest activities of the microbial communities were observed in July in the surface layers $(0-1 \mathrm{~cm})$, with a strong decrease of activities with depth. In contrast, in February, low microbial bulk activities were recorded throughout the sediment. In general, prokaryotic abundances and activities were significantly correlated. Variation partitioning analysis suggested a low impact of predation and a mainly bottom-up-controlled prokaryotic community. Hence, in the top layer from the surface to $1-3.5 \mathrm{~cm}$ depth, microbial communities were mainly affected by physicochemical variables (i.e., salinity, phosphate and silicate concentrations). Below this zone and at least to $10 \mathrm{~cm}$ depth, environmental variables were more stable and prokaryotic activities were low. The transition zone between both layers probably represents a rather smooth gradient (environmental ecocline). The results of our study provide a better understanding of the complex interactions between micro-organisms and their environment in a fluctuating ecosystem such as an intertidal mudflat.

Keywords: intertidal mudflat, sediment depth, microbial communities, benthic ecology 


\section{Introduction}

In temperate zones, intertidal mudflats are among the most productive coastal ecosystems due to the development of an active microphytobenthic biofilm at the surface of the sediment (Admiraal, 1984; Underwood and Kromkamp, 1999). Several factors drive the high productivity levels such as incident light and large nitrogen-rich inputs from the continent (Underwood and Kromkamp, 1999), in these complex ecosystems. The knowledge about the relationship between the microphytobenthos and the activity of prokaryotic communities, although recognized as of paramount importance for determining the productivity of these ecosystems (Agogué et al., 2014; Decho, 2000; McKew et al., 2013; Orvain et al., 2014a), is still largely insufficient (Van Colen et al., 2014). Marine coastal sediments harbor among the most diverse and abundant prokaryotic communities (Whitman et al., 1998; Zinger et al., 2011). The abundances and activities of these microbial communities seem to vary along a vertical gradient at a restricted vertical scale $($ e.g., $<20 \mathrm{~cm})$ under the influence of the 1) organic matter composition and quality and electron acceptor availability (Kristensen, 2000), 2) physical properties of the sediments, 3) bioturbation and bioirrigation activities 4) bottom-up and topdown trophic controls, and 5) climatic conditions.

The dominant source of carbon for heterotrophic microorganisms in temperate intertidal mudflats is derived from microphytobenthic activities (i.e., photosynthesis and exopolymeric substance production) (Underwood and Kromkamp, 1999). This organic matter production is primarily ensured by epipelic (i.e., motile free-living) diatoms and quickly transferred to other biological compartments (Middelburg et al., 2000). The microphytobenthic biofilm has such a relevant effect on prokaryotic communities at low tide that it drastically modifies the remineralization and fluxes of inorganic nutrients across the sediment surface (Middelburg et al., 2000). 
In muddy fine-grained low-permeable sediments, where advection fluxes are almost absent, physical transport of solutes is mainly driven by molecular diffusion within the interstitial water. The top sediment layers show a strong consumption of oxygen by organotrophic microorganisms and by reoxidation of reduced compounds such as $\mathrm{Fe}^{2+}, \mathrm{Mn}^{2+}$, $\mathrm{H}_{2} \mathrm{~S}$ (Soetaert et al., 1996). Hence, oxygen does not diffuse below the first few millimeters in mudflats where deeper sediment are most often anoxic (Bertics and Ziebis, 2010). Other inorganic electron acceptors, including the nutrient nitrate, can thus be used deeper in the sediment by dissimilatory processes (e.g., denitrification) for anaerobic mineralization. Hence, microbial communities may exhibit vertical patterns in the nature and rate of their activity in response to changing biogeochemical conditions, implicating different prokaryotic assemblage. Moreover, infauna activity plays a crucial role in the modulation of microbial activity in sediments by disturbing the vertical gradients of oxygen, organic matter and inorganic nutrients (Bertics and Ziebis, 2009; Gilbertson et al., 2012; Jones et al., 1996). As an example, prokaryotic activity has been shown to be increased by both bioirrigation and bioturbation activities in a coastal lagoon of the Santa Catalina Island (CA, USA) (Bertics and Ziebis, 2009). Furthermore, prokaryotes may strongly vary under trophic controls. The impact of the availability of resources (e.g., organic matter and/or inorganic nutrients) is defined as the bottom-up control of the microbial communities (Fuhrman and Hagström, 2008), and may strongly change at both spatial and temporal scales. On the other hand, top-down control is described as grazing pressure primarily carried out by meiofauna or viruses (i.e., prokaryotic cell lysis) in intertidal mudflats. Among the few studies focusing on the balance of bottomup/top-down control in mudflats, the role of top-down control by meiofauna seems to be significant and could be more important than bottom-up control (Fabiano and Danovaro, 1998), although a local study indicated that grazing pressure did not represent a crucial control of bacterial community (Pascal et al., 2009). In a microcosm study, De Mesel et al. (2004) 
highlighted that both trophic controls have to be considered as bacterial community structure is

99 a function of substrate but the relative abundance of each taxa is influenced by the grazing activities of bacterivorous nematods.

Finally, in intertidal zones and especially in macrotidal systems, the alternation of

102 emersion and immersion produces drastically fluctuating conditions, particularly during low

103 tide at the sediment surface. For example, temperature, a key factor impacting prokaryotic

104 metabolism in coastal sediments (Hubas et al., 2007), can fluctuate significantly within 6 hours

105 of a low tide (until $16^{\circ} \mathrm{C}$ of amplitude measured at the sediment surface in the Marennes Oléron

106 mudflat, France, Orvain et al. (2014a)). Moreover, in these shallow ecosystems, other climatic

107 conditions such as wind or waves can strongly disturb the global (i.e., biotic and abiotic) vertical

108 zonation of the sediment (Dupuy et al., 2014).

109 The aims of this study were 1) to describe stratification patterns of the activities and 110 densities of prokaryotic communities in coastal mudflats at $\mathrm{cm}$-scale spatial resolution and 2) to

111 statistically disentangle the relative contributions of environmental variables and meiofauna

112 abundances in the different depth layers as possible drivers for these prokaryotic activities and

113 densities. This work was focused on an intertidal mudflat in Marennes-Oléron Bay (SW France)

114 sampled twice at low tide, during representative summer and winter conditions, respectively in

115 assessed how the patterns of prokaryotic densities and activities varied with depth and to

116 identify the impact of physicochemical variables and potential grazing pressure on the

117 stratification observed. 


\section{Materials and Methods}

\subsection{Study site and sampling}

Sediment cores were sampled in Marennes-Oléron Bay on the Atlantic French coast $(1 \mathrm{~km}$ from the shore) (N $\left.45^{\circ} 54^{\prime} 53^{\prime \prime} ; \mathrm{W} 01^{\circ} 05^{\prime} 23^{\prime \prime}\right)$. The intertidal mudflat is characterized by the presence of parallel ridges and runnels and sampling was performed on ridges at low tide. Two sampling dates were compared at a similar tidal range (5.5 $\pm 0.2 \mathrm{~m})$ : 1) on July 5,2012 , high temperature and incident irradiance and 2) on February 11, 2013, low temperature and incident irradiance.

On each sampling date, triplicate $15-\mathrm{cm}$ diameter cores were sliced in situ into five layers using a piston inserted below the core from 0 to $10 \mathrm{~cm}$ below the sediment surface (bsf) (D1 = 0-0.5 cm; D2 $=0.5-1 \mathrm{~cm} ; \mathrm{D} 3=1-2 \mathrm{~cm} ; \mathrm{D} 4=2-5 \mathrm{~cm}$ and D5 $=5-10 \mathrm{~cm})$. Samples were homogenized and subdivided using 50-ml sterile syringes with cut-off tips for further analysis (storage conditions differed according to the variable, see Supp info Table S1). Triplicate cores 12-cm in diameter were simultaneously recovered for the determination of pore-water nutrient concentrations. These cores were pre-drilled vertically at $0.5 \mathrm{~cm}$ resolution, and pore water was collected at $0.5,1,1.5,3.5$ and $7.5 \mathrm{~cm}$ bsf, using the Rhizons ${ }^{\circledR}$ (Rhizosphere Research Products Netherlands ) method (Seeberg-Elverfeldt et al., 2005). The Rhizons were inserted horizontally into the sediment core during 20 minutes to collect enough pore-water volume for subsequent analysis.

\subsection{Physical and chemical analysis}

Incident irradiance and temperature at the surface of the sediment were assessed in situ every 30 seconds with a universal light-meter and data logger (ULM-500, Walz Effeltrich, Germany) equipped with a plane light/temperature sensor (accessory of the ULM-500) and a plane cosine quantum sensor (Li-COR, USA). Depth temperature profiles were measured every 
30 seconds during all the sampling period with five 3.1-cm length Hobo sensors (Hobo Pro V2,

143 USA) fixed on a homemade stick that was vertically pushed into the sediment to position the 144 sensors at 5 different depths $(0.5 \mathrm{~cm}, 1 \mathrm{~cm}, 2 \mathrm{~cm}, 5 \mathrm{~cm}$ and $10 \mathrm{~cm} \mathrm{bsf})$.

At the laboratory, pore-water $\mathrm{pH}$ and salinity (using the Practical Salinity Scale) were measured in the supernatant after centrifugation $\left(15 \mathrm{~min}, 3,000 \times g\right.$ at $\left.8{ }^{\circ} \mathrm{C}\right)$ with a $\mathrm{pH}$ probe

147 (Eutech Instruments PC150, USA) and a conductivity meter (Cond 3110, TetraCon 325, WTW,

148 Germany), respectively. Sediment density and porosity were evaluated by weighing $50 \mathrm{ml}$ of 149 fresh sediment before and after drying $\left(48 \mathrm{~h}\right.$ at $\left.60{ }^{\circ} \mathrm{C}\right)$. Porosity was calculated as the ratio of 150 the volume of water divided by the total volume of sediment. After removal of salts and organic 151 matter, the mean grain size of the sediment was measured by a laser granulometer (Mastersizer 152 2000, Malvern Instruments, U.K.) and evaluated using the GRADISTAT program (Blott and 153 Pye, 2001) according to the Folk and Ward theory (Folk and Ward, 1957). Total organic carbon (TOC) and total nitrogen (TN) contents were measured on lyophilized samples by oxic combustion at $950^{\circ} \mathrm{C}$ (Strickland and Parsons, 1972) using a CHN 156 elemental analyzer (Thermo Fisher Flash EA 1112, Waltham, MA, USA). Samples for TOC 157 were decarbonated (in hydrochloric acid, $\mathrm{HCl} 1 \mathrm{~N}$ ) prior to combustion to remove the inorganic 158 carbon. Because the decarbonation could biased the TN content analysis, subsamples were ran 159 before and after decarbonation to validate the TN measurement. Two exopolymeric (EPS) fractions (colloidal and bound) were extracted in two steps:

161 colloidal EPS were extracted using fresh sediment mixed with an equal volume of artificial 162 seawater, then bound EPS were extracted using the residual sediment mixed with Dowex resin 163 (Takahashi et al., 2009). Before quantification of EPS-proteins and -carbohydrates, each extract 164 was vacuum-evaporated over 6h (Maxi Dry plus, Heto, Denmark). Colloidal and bound EPS165 protein concentrations were determined using the bicinchoninic acid assay (Smith et al., 1985). 166 Colloidal and bound EPS-carbohydrate concentrations were determined according to the 
167 phenol-sulfuric acid method (Dubois et al., 1956). The four resulting fractions colloidal EPS-

168 proteins, bound EPS-proteins, colloidal EPS-carbohydrates and bound EPS-carbohydrates were 169 expressed in $\mu \mathrm{g} \mathrm{g}^{-1}$ sed DW. Colloidal EPS correspond to the sum of colloidal EPS-proteins 170 and colloidal EPS-carbohydrates. Bound EPS correspond to the sum of bound EPS-proteins 171 and bound EPS-carbohydrates. Colloidal EPS and bound EPS were used for the calculation of 172 the ratio colloidal EPS / bound EPS. EPS-carbohydrates correspond to the sum of colloidal

173 EPS-carbohydrates and bound EPS-carbohydrates. EPS-proteins correspond to the sum of colloidal EPS-proteins, bound EPS-proteins. EPS-carbohydrates and EPS-proteins were used

175 for the calculation of the ratio EPS-carbohydrates/EPS-protein.

176 Total protein content was determined in sediment (stored at $\left.-20^{\circ} \mathrm{C}\right)$ after extraction $(30$ 177 min, in the dark, $+4{ }^{\circ} \mathrm{C}$ in $0.2-\mu \mathrm{m}$-filtered seawater) using Lowry Peterson's modification assay 178 (Sigma-Aldrich). Ammonium $\left(\mathrm{NH}_{4}{ }^{+}\right)$, nitrites $\left(\mathrm{NO}_{2}{ }^{-}\right)$, nitrates $\left(\mathrm{NO}_{3}{ }^{-}\right)$, phosphate $\left(\mathrm{PO}_{4}{ }^{3-}\right)$, and 179 silicate $\left(\mathrm{Si}(\mathrm{OH})_{4}\right)$ concentrations were determined using an autoanalyzer (Seal Analytical, 180 GmbH Nordertedt, Germany) equipped with an XY-2 sampler according to Aminot and 181 Kérouel (2007). Chlorophyll $a$, used as a proxy of algal biomass, was assessed by fluorimetry (640 $\mathrm{nm}$,

184 Turner TD 700, Turner Designs, USA) after extraction with 90\% acetone. Chlorophyll $a$ 185 concentrations were expressed as $\mu \mathrm{g} \mathrm{g}^{-1}$ sediment dry weight (DW) according to Lorenzen 186 (1966). Prokaryotic abundance was evaluated by flow cytometry after a cell extraction 187 procedure described by Lavergne et al. (2014). Analyses of the two potential extracellular enzymatic activities, $\beta$-glucosidase and 189 aminopeptidase, were determined by spectrofluorimetry (Boetius, 1995) (SAFAS Scientific 190 Instruments, Monaco) [excitation/emission $=\beta$-glucosidase activity: $365 \mathrm{~nm} / 460 \mathrm{~nm}$; and 
aminopeptidase: $340 \mathrm{~nm} / 410 \mathrm{~nm}$ ]. For $\beta$-glucosidase activity, slurry sediment samples were

192 incubated in triplicate using 4-Methylumbelliferyl $\beta$-D-glucopyranoside $\left(500 \mu \mathrm{mol} \mathrm{L}^{-1}\right.$ final conc.) as a substrate at three different incubation times: 15, 45, and 75 min. For aminopeptidase activity, slurry sediment samples were incubated in triplicate with L-leucine $\beta$-naphthylamide hydrochloride (300 $\mu \mathrm{mol} \mathrm{L} \mathrm{L}^{-1}$, final conc.) as a substrate at three different incubation times: 10 , 30, and $60 \mathrm{~min}$. Final concentrations of 4-Methylumbelliferyl $\beta$-D-glucopyranoside and Lleucine $\beta$-naphthylamide hydrochloride were determined previously to represent saturation levels and maximum yield velocities $\left(\mathrm{V}_{\max }\right)$ (Boetius and Lochte, 1996). bacterial production (Garet and Moriarty, 1996; Pascal et al., 2009). Briefly, $30 \mu 1$ of fresh sediment slurry (vol/vol; 0.2- $\mu \mathrm{m}$-filtered seawater) was incubated with ${ }^{3} \mathrm{H}$-thymidine $0.74 \times$ $10^{6} \mathrm{~Bq}$ for $1 \mathrm{~h}$ at in situ temperature $\left(22^{\circ} \mathrm{C}\right.$ in July and $12^{\circ} \mathrm{C}$ in February). Blank controls were stopped just after the addition of labelled ${ }^{3} \mathrm{H}$-thymidine with $8 \mathrm{ml}$ of cold $80 \%$ ethanol. After incubation, samples were stopped with $8 \mathrm{ml}$ of cold ethanol (80\%). After two washes with $80 \%$ cold ethanol by mixing and centrifugation $\left(15 \mathrm{~min}, 4500 \mathrm{~g},+4^{\circ} \mathrm{C}\right)$, slurries were transferred with $2 \mathrm{~mL}$ of ice-cold TCA (5\%, trichloroacetic acid) onto a polycarbonate filter (Nuclepore $0.2 \mu \mathrm{m}, 25 \mathrm{~mm}$, Millipore, NJ, USA). Subsequently, the filters were washed four times with $5 \%$ ice-cold TCA. Afterwards, the filters were transferred into scintillation vials containing 2 $\mathrm{ml} 0.5 \mathrm{~N}$ chlorhydric acid and incubated $16 \mathrm{~h}$ at $+95^{\circ} \mathrm{C}$ (Garet and Moriarty, 1996). Supernatant $(0.5 \mathrm{~mL})$ was transferred in a new scintillation vial with $5 \mathrm{~mL}$ of scintillation fluid (Ultima

211 Gold, Perkin-Elmer, MA, USA). The amount of radioactivity in each vial was measured using a scintillation counter (Perkin-Elmer, USA). Benthic bacterial production was finally expressed

213 as pmol ${ }^{3} \mathrm{H}^{\text {Thy }} \mathrm{g}^{-1}$ sed $\mathrm{DW} \mathrm{h}{ }^{-1}$ using a conversion factor $4.51 \times 10^{-13}\left(\mathrm{Ci} \mathrm{dpm}^{-1}\right)$ evaluated 214 experimentally to account for counter efficiency. 
For meiofaunal assemblage determination, samples from each depth $(60 \mathrm{~mL})$ were

216 stored directly after sampling at room temperature in absolute ethanol, sieved through $50 \mu \mathrm{m}$

217 before staining with rose Bengal and observation under stereo microscope (Zeiss). Foraminifera

218 were counted in all the sediment samples, and for other meiofauna organisms (i.e., juvenile

219 gastropods, copepods, ostracods, nematods, foraminifera, and juvenile bivalves), samples were

220 diluted prior to counting. Abundances were expressed as individuals (ind.) per $\mathrm{cm}^{3}$.

221 Additionally, six 20-cm diameter PVC cores were harvested at each date and sieved through 1

$222 \mathrm{~mm}$. The macrofauna was collected and stored in ethanol $60 \%$ for further identification. In the

223 current study, only the data of the abundance of the macrozoobenthic grazer, Peringia ulvae

224 (Pennant, 1777) are presented. The mean abundance of the six cores is expressed in ind $\mathrm{m}^{-2}$.

\subsection{Statistical analyses}

All statistical analyses were performed with R software (R Core Team, 2013). In this study, the results are presented as the means \pm standard error (SE) because the SE evaluates the mean estimation imprecision. To evaluate the effect of temperature on thymidine incorporation rate, $\mathrm{Q}_{10}$ values were calculated at each sampling depth (Lomas et al., 2002) using the Equation 2301.

Equation 1: $Q_{10}=(R 2 / R 1)^{\left(10 / t_{2}-t_{1}\right)}$

Where $R 2$ and $R l$ are the thymidine incorporation rates and $t_{2}$ and $t_{1}$ are the incubation temperatures in July and February, respectively. This factor indicating the increase of a process rate with $10^{\circ} \mathrm{C}$ increase of temperature is more powerful when calculated with large dataset and/or used with regression data (Hubas et al., 2007; Lomas et al., 2002). In the current study, as the replicates are independent between the two sampling dates, $\mathrm{Q}_{10}$ factor was calculated for 
all the possible combinations $\left(n=3^{3}\right)$. Then, a student test for one sample was used to evaluate whether the $\mathrm{Q}_{10}$ values were significantly different from 1.

Pearson tests were used to test whether the distribution of two variables was similar. The significant variation of environmental and prokaryotic variables among sediment depths and sampling dates was evaluated by two-way ANOVA (using sampling date - 2 levels - and depths - 5 levels - as factors) followed by multiple comparison tests (Tukey HSD test) and variance homogeneity and residuals normality were tested. For the two variables "chlorophyll a" and "Q ${ }_{10}$ of thymidine incorporation", the ANOVA assumptions were violated, the variables were ln-transformed and two-way ANOVA followed by Tukey HSD test was performed. For the two variables "EPS-carbohydrates/EPS-protein" and "colloidal EPS/ bound EPS", the ANOVA assumptions were violated and transformation was not possible, non-parametric Friedman test was thus run followed by the Nemenyi post-hoc test for multiple joint samples (Nemenyi, 1963; Sachs, 1997) using the "PMCMR" package (Pohlert, 2014).

Multivariate principal component analysis (PCA) was performed for July sampling and February sampling separately with 8 environmental variables using the "FactoMineR" package (Husson et al., 2013). Then, in order to define sediment horizons using the basis of each PCA obtained, a hierarchical clustering analysis was applied using the HCPC function of the "FactoMineR" package (Husson et al., 2013).

Finally, in order to disentangle the impacts of the environmental variables and meiofaunal group abundance, both taken individually as well as shared, on the distribution of prokaryotic density and activities, variation partitioning was performed (Borcard et al., 1992; Ramette, 2007; Volis et al., 2011) using the varpart function of the "vegan" packages (Oksanen et al., 2013)). First, one response table and three explanatory tables were built and composed as follows. The response table corresponds to the "prokaryotic" table (P table) containing prokaryotic abundance (PA), thymidine incorporation (Thy.inc), aminopeptidase activity 
262 (AMA), and $\beta$-glucosidase activity (BGA) and was standardized to unit variance. The 263 explanatory "meiofauna" table ( $\mathrm{M}$ table) containing abundances of juvenile gastropods, 264 copepods, ostracods, nematods, foraminifera, and juvenile bivalves was $\log 10(\mathrm{x}+1)$ 265 transformed to normalize the distribution. And the explanatory table of the "environmental 266 variables" (E table) (standardized) contains temperature, salinity, $\mathrm{pH}$, the ratio $\mathrm{DIN}: \mathrm{PO}_{4}{ }^{3-}$, the 267 ratio TOC:TN, total protein content, porosity, EPS-carbohydrates/EPS-protein and colloidal 268 EPS/bound EPS. Using forward selection procedure (Legendre and Legrendre, 1998) with the function forward.sel in the package 'packfor' (Dray et al., 2013), we selected the variables that influenced the most the response table (Ramette and Tiedje, 2007). The final explanatory tables 272 was thus composed as follows: the table E containing phosphate and silicate concentrations as 273 well as salinity and the table M containing abundance of juvenile gasteropods. The variation partitioning evaluates diverse components of variation of a set of response variables: 1) the pure effect of each individual explanatory table without the effect of the other explanatory table; 2) the redundancy of the two explanatory tables which is the part of the variance explained by both 277 explanatory tables; and 3) the residual effects unexplained by the chosen variables (Borcard et 278 al., 1992; Volis et al., 2011). In this set of data, it is expected that the distribution of abundances and activities of prokaryotes (P table) responds linearly to the explanatory variables, thus we used the linear-based PCA and redundancy analysis (RDA) for the analysis. The total variance to be explained was evaluated by a PCA with the abundances and activities of prokaryotes (P 282 table). RDA was used to assess the amount of variation of the $\mathrm{P}$ table explained by the two 283 explanatory variables (as constraining variables). Using partial RDA (pRDA), the effect of a 284 set of variable (an explanatory table) could be removed from the analysis if selected as a covariable. This is an important issue of this multivariate analysis that, in the present case, evaluates for example the effect of meiofauna on prokaryotic variables without the effect of the 
environmental variables. These environmental variables such as salinity could indeed be important factors for both prokaryotic and meiofaunal communities and the partition of these effects allows to quantify the pure effect of the meiofauna without the shared variation with environmental variables. Finally, the significance of each ordination was tested by an ANOVA like permutation test using 9999 permutations (Volis et al., 2011).

\section{Results}

\subsection{Environmental conditions and variation of physicochemical variables}

The air temperature and incident irradiance at the surface of the mudflat were $28 \pm$ $0.9{ }^{\circ} \mathrm{C}$ and $1800 \pm 156 \mu \mathrm{mol}$ photons $\mathrm{m}^{-2} \mathrm{~s}^{-1}$ and $10.5 \pm 1.1^{\circ} \mathrm{C}$ and $611 \pm 292 \mu$ mol photons $\mathrm{m}^{-}$ ${ }^{2} \mathrm{~s}^{-1}$ during the samplings in July and in February, respectively (Supp info Fig. S1 and Table S2). The sediment was predominantly silt-clay (mean of 91.2\%), with an average grain size of $11.17 \pm 0.34 \mu \mathrm{m}$ and a porosity of $0.73 \pm 0.01$

Two-way ANOVA reveals that all the physicochemical variables (presented in the Table 1) were significantly different between the two sampling dates $(p<0.05)$ except the Colloidal EPS / bound EPS ratio. Significant variations with sediment depth are highlighted by Tukey's post hoc test (Table 1, see Supp info Fig. S2 to Fig. S4 for detailed profiles).

Then, two principal component analysis (PCA) were performed using 8 variables (i.e., presented in the Table 1 except grain size, porosity and algal biomass) aiming at describing the interactions within the physicochemical variables for each sampling date and a hierarchical clustering analysis based on the ordinations obtained was used to group the samples. In July, the two first dimensions of the PCA together explained $66.68 \%$ of the observed variability in the dataset (Figure 1a). The first dimension was mostly characterized by TOC:TN, pH, salinity and temperature and differentiated the samples in two groups from 0 to $1 \mathrm{~cm} \mathrm{bsf}$ on one hand 
310 and the samples from 1 to $10 \mathrm{~cm}$ bsf on the other hand (Figure 1c). In February, the two first 311 dimensions of the PCA together explained $68.94 \%$ of the observed variability in the dataset 312 (Figure 1b). The first dimension was mostly characterized by TOC:TN, $\mathrm{pH}$ and temperature 313 and differentiated the samples in two groups from 0 to $2 \mathrm{~cm}$ bsf on one hand and the samples 314 from 2 to $10 \mathrm{~cm}$ bsf on the other hand (Figure 1d).

315 In both cases, DIN:PO ${ }_{4}^{3-}$ and EPS-carbohydrates/EPS-proteins ratios have information 316 represented in both dimensions of the ordinations. 
317 Table 1. Average of each environmental variables and algal biomass ( \pm SE) along sediment depths. Two-way ANOVA reveals always significant $\mathrm{d}$

318 letters in bold font indicate Tukey's post hoc test for each sampling date.

\begin{tabular}{|c|c|c|c|c|c|c|c|c|c|c|c|c|c|c|c|c|c|c|c|c|}
\hline \multirow{2}{*}{\multicolumn{2}{|c|}{$\begin{array}{c}\text { Grain size }^{1} \\
\mu \mathrm{m}\end{array}$}} & \multirow{2}{*}{\multicolumn{3}{|c|}{ Porosity }} & \multirow{2}{*}{\multicolumn{3}{|c|}{ Salinity }} & \multirow{2}{*}{\multicolumn{2}{|c|}{ pH }} & & \multirow{2}{*}{\multicolumn{3}{|c|}{ Temperature }} & \multirow{2}{*}{\multicolumn{3}{|c|}{ TOC:TN ${ }^{2}$}} & \multirow{2}{*}{\multicolumn{3}{|c|}{ DIN:PO${ }^{3-}$}} & \\
\hline & & & & & & & & & & & & & & & & & & & & \\
\hline Mean & $S E$ & Mean & $S E$ & & Mean & $S E$ & & Mean & $S E$ & & Mean & $S E$ & & Mean & $S E$ & & Mean & $S E$ & & $\overline{\mathrm{Mea}}$ \\
\hline 9.1 & 0.3 & 0.78 & 0.02 & $\mathbf{a}$ & 45.4 & 2.3 & $\mathbf{a}$ & 7.5 & 0.1 & $\mathbf{a}$ & 22.2 & 2.9 & $\mathbf{a}$ & 6.06 & 0.03 & $\mathbf{a}$ & 9.10 & 3.86 & $\mathbf{a}$ & \\
\hline 8.7 & 0.5 & 0.72 & 0.01 & $\mathbf{a b}$ & 37.5 & 0.2 & b & 7.0 & 0.0 & b & 22.2 & 0.9 & $\mathbf{a}$ & 6.27 & 0.03 & $\mathbf{a}$ & 54.65 & 21.12 & $\mathbf{a b}$ & \\
\hline 9.3 & 0.1 & 0.69 & 0.03 & $\mathbf{a b}$ & 34.3 & 0.1 & b & 6.7 & 0.1 & b & 21.9 & 0.6 & $\mathbf{a}$ & 6.45 & 0.03 & $\mathbf{a}$ & 21.88 & 1.09 & b & \\
\hline 10.7 & 0.2 & 0.69 & 0.00 & b & 33.5 & 0.8 & b & 6.6 & 0.0 & c & 21.5 & 0.3 & $\mathbf{a b}$ & 6.62 & 0.09 & $\mathbf{a}$ & 175.10 & 100.58 & $\mathbf{a b}$ & \\
\hline 11.0 & 0.4 & 0.68 & 0.02 & b & 33.4 & 0.5 & b & 6.9 & 0.1 & b & 20.8 & 0.2 & b & 6.59 & 0.04 & $\mathbf{a}$ & 241.58 & 79.25 & $\mathbf{a b}$ & \\
\hline 14.4 & $N A$ & 0.77 & 0.03 & $\mathbf{a}$ & 24.3 & 0.2 & $\mathbf{a b}$ & 7.9 & 0.0 & $\mathbf{a}$ & 9.5 & 2.1 & $\mathbf{a}$ & 6.75 & 0.17 & $\mathbf{a}$ & 57.09 & 14.26 & $\mathbf{a}$ & \\
\hline 13.2 & $N A$ & 0.75 & 0.00 & $\mathbf{a b}$ & 23.5 & 0.8 & $\mathbf{a}$ & 7.2 & 0.1 & b & 8.8 & 1.2 & $\mathbf{a b}$ & 7.20 & 0.08 & $\mathbf{a}$ & 18.66 & 7.84 & abc & \\
\hline 10.5 & $N A$ & 0.79 & 0.03 & $\mathbf{a b}$ & 23.6 & 1.0 & $\mathbf{a b}$ & 7.2 & 0.2 & b & 9.2 & 0.5 & ab & 7.35 & 0.13 & b & 6.87 & 2.06 & $\mathbf{a b}$ & \\
\hline 11.9 & $N A$ & 0.71 & 0.02 & b & 26.3 & 1.8 & $\mathbf{a b}$ & 7.0 & 0.1 & b & 8.8 & 0.7 & $\mathbf{a b}$ & 7.47 & 0.13 & b & 11.52 & 1.74 & bc & \\
\hline 13.0 & $N A$ & 0.69 & 0.01 & b & 29.5 & 1.7 & b & 7.0 & 0.1 & b & 8.4 & 0.2 & b & 8.00 & 0.16 & b & 19.54 & 6.14 & c & \\
\hline
\end{tabular}

\footnotetext{
${ }^{1}$ Note that triplicates were not available for grain size for February sampling (NA: not available)

${ }^{2}$ TOC:TN : ratio of total organic carbon (TOC) to total nitrogen (TN). TOC and TN are in $\mu \mathrm{g} \mathrm{g}^{-1}$ sed DW

${ }^{3}$ EPS-carbohydrates/EPS-protein and colloidal EPS/bound EPS are ratios without unit. Colloidal EPS-proteins, bound EPS-proteins, colloidal EPS-carbohydrat
} 
a) July

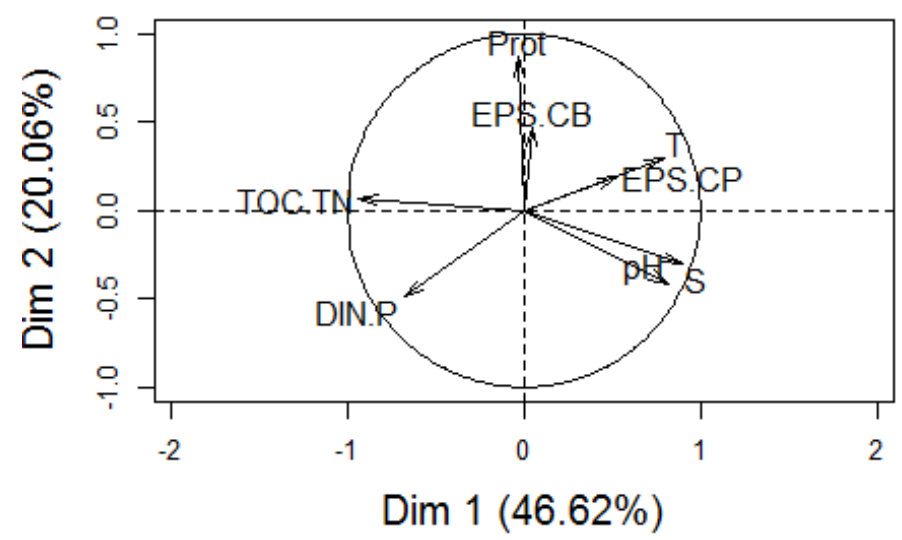

c) July

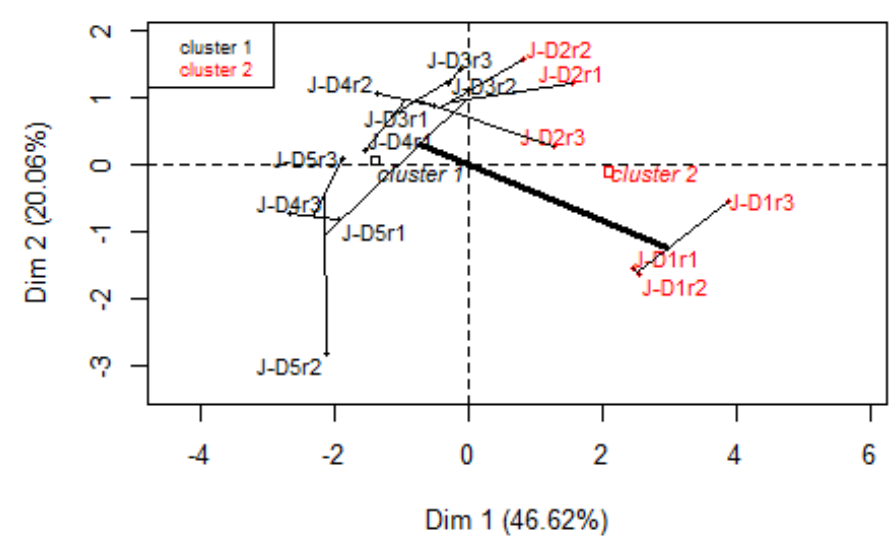

b) February

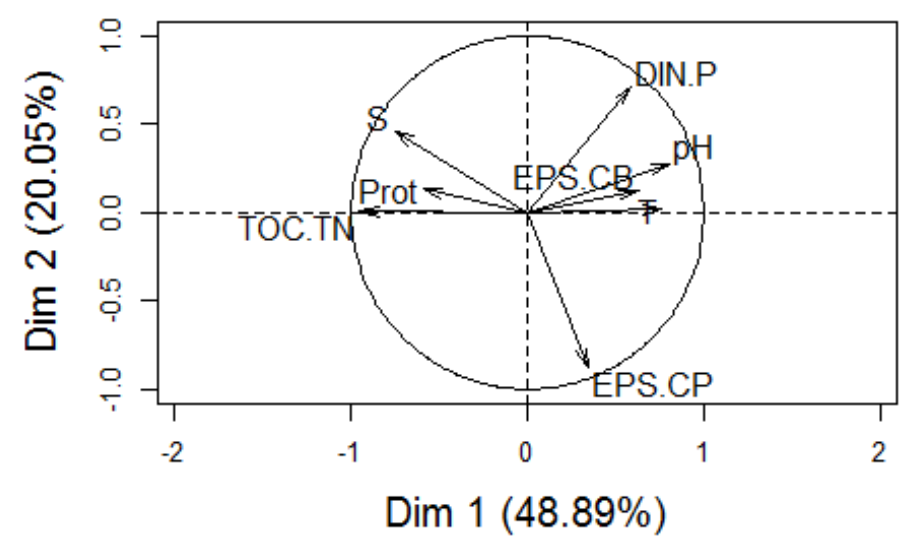

d) February

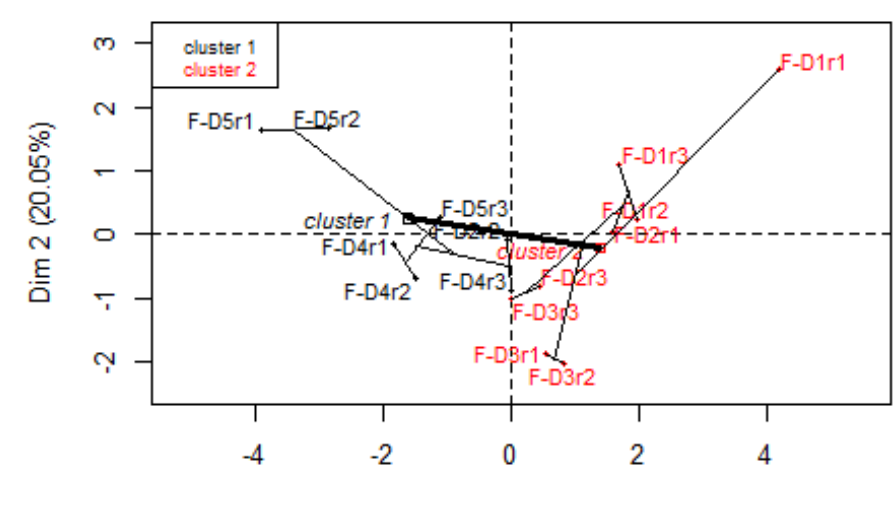

$\operatorname{Dim} 1(48.89 \%)$

321 Figure 1. Principal component analysis (PCA) ordination calculated using 8 physico-chemical

322 variables for a and c) 15 samples in July and b and d) 15 samples in February. a and b)

323 Ordination of the variables and correlation circle. $b$ and d) Position of the observations in the

324 ordination; tree calculated hierarchical classification on principle components and the different

325 clusters evaluated using 10000 iterations . T: temperature; S: salinity; Prot: total protein

326 concentration; EPS.CB: colloidal EPS/bound EPS ratio; EPS.CP: EPS-carbohydrates/EPS-

327 proteins ratio; DIN.P: DIN:PO ${ }_{4}^{3-}$ ratio; TOC:TN: ratio of total organic carbon (TOC) and total 328 nitrogen (TN). PCA and hierarchical classification were performed using "FactoMineR" 329 package (Husson et al., 2013). 
331 Prokaryotic abundances ranged from $1.18 \pm 0.20 \times 10^{10}$ to $3.45 \pm 1.05 \times 10^{10}$ cells $\mathrm{g}^{-1} \mathrm{sed} \mathrm{DW}^{\mathrm{N}}$

332 in July with maximum values in the surficial sediment layer $(0-0.5 \mathrm{~cm}$ below the sediment

333 surface) (Figure 2). Abundances were significantly lower in February than in July (two-way 334 ANOVA, F=24.16, $p<0.001$, Supp info Table S3) with values between $1.08 \pm 0.75 \times 10^{10}$ and

$3351.72 \pm 0.50 \times 10^{10}$ cells $\mathrm{g}^{-1}$ sed DW and a peak recorded between 0.5 and $1 \mathrm{~cm}$ bsf. In July, 336 thymidine incorporation (a proxy for benthic bacterial production) decreased with depth from $189.69 \pm 8.15$ to $46.31 \pm 9.93$ pmol ${ }^{3} \mathrm{H}$-Thy $\mathrm{g}^{-1}$ sed $\mathrm{DW} \mathrm{h}^{-1}$. In February, thymidine incorporation was lower but showed a similar decrease with depth. For both sampling dates, thymidine incorporation and prokaryotic abundance distribution profiles were very similar

340 (Pearson test, $\mathrm{n}=30 \mathrm{r}^{2}=0.806, p<0.001$ ) (Figure 2). The impact of a $10^{\circ} \mathrm{C}$-increase on 341 thymidine production was expressed by using $\mathrm{Q}_{10}$. The temperature had a strong impact on 342 thymidine production between 0 and $0.5 \mathrm{~cm}$ bsf (average value of $\mathrm{Q}_{10}=6.265$ ). Then, between 3430.5 and $1 \mathrm{~cm}$ bsf, temperature effect was less important (average value of $\mathrm{Q}_{10}=1.589$ ) but 344 significantly different from 1 ( $\mathrm{t}$-test one sample, $\mathrm{t}=3.4589, p=0,009$ ). Between 1 and $10 \mathrm{~cm}$ 345 bsf, the temperature had no effect as $\mathrm{Q}_{10}$ values were not significantly different from 1 ( $\mathrm{t}$-test 346 one sample, $p>0.01)$.

347 Variance analysis (two-way ANOVA) showed that potential aminopeptidase activity was 348 significantly higher in July $(\mathrm{F}=75.29, p<0.001$, Supp info Table S3) (mean for all depth: 381.31

$349 \pm 78.64 \mathrm{nmol} \mathrm{g}^{-1} \mathrm{sed} \mathrm{DW} \mathrm{h}^{-1}$ ) than in February (mean for all depth: $88.02 \pm 13.60 \mathrm{nmol} \mathrm{g}^{-1} \mathrm{sed}$ $350 \mathrm{DW} \mathrm{h}^{-1}$ ) and that in July, these activities were significantly different in the surface sediment 351 compared to the deeper layers (Tukey HSD test, $p<0.001$ ) (Figure 2). Potential $\beta$-glucosidase 352 activity was generally low throughout all the sediment depths. Values ranged from $6.71 \pm 1.09$ 
353 to $18.14 \pm 1.42 \mathrm{nmol} \mathrm{g}^{-1}$ sed DW h${ }^{-1}$ in July and from $3.49 \pm 1.21$ to $41.59 \pm 8.32 \mathrm{nmol} \mathrm{g}^{-1}$ sed $354 \mathrm{DW} \mathrm{h}^{-1}$ in February (Figure 2). 


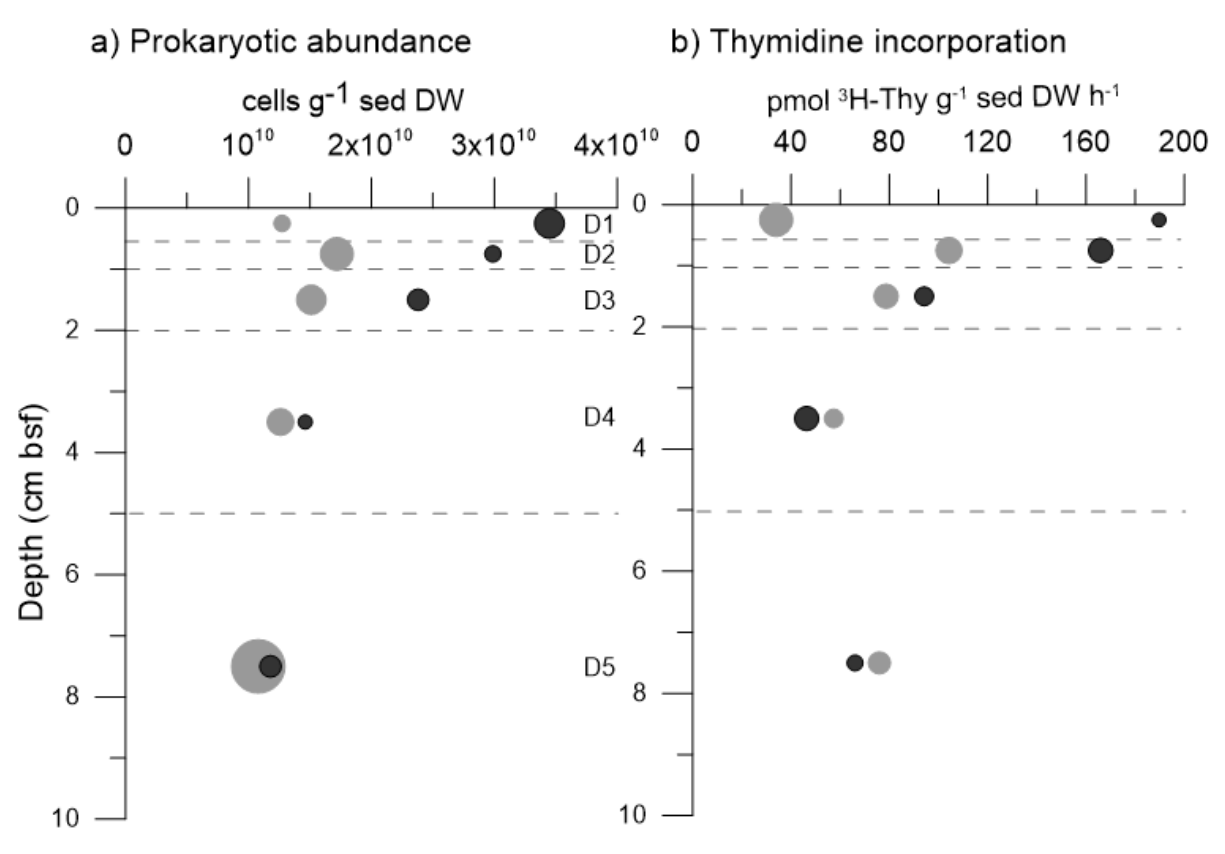
c) Aminopeptidase activity
d) Beta-glucosidase activity

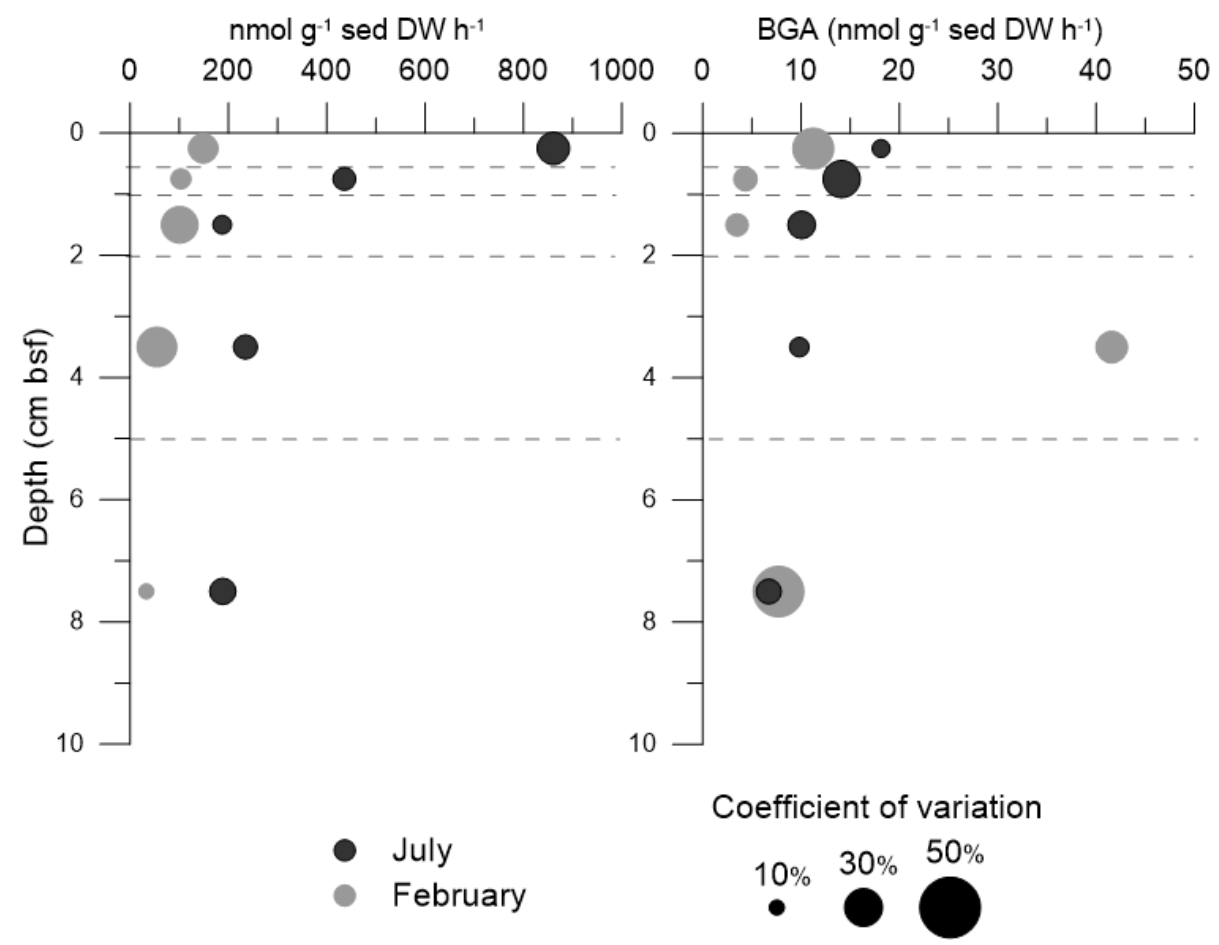

Figure 2. Prokaryotic abundances, production and activities along a vertical depth 357 gradient below the sediment surface (bsf). All points represent the middle of each layer. The 358 coefficient of variation is displayed as bubble size. Black bubbles represent values for July 5 , 359 2012, and gray bubbles represent values for February 11, 2013. 


\subsection{Algal biomass}

The algal biomass on the surface (D1) was $69.5 \pm 2.4 \mu \mathrm{g} \mathrm{Chl} a \mathrm{~g}^{-1}$ sed DW $59.4 \pm 1.7 \mu \mathrm{g}$

362 Chl $a \mathrm{~g}^{-1}$ sed DW during the samplings in July and in February, respectively (Table 1). The highest standard errors were recorded in D1, resulting probably from the patchiness distribution of the microphytobenthos observed in the field. The algal biomass showed an exponential decrease with values never exceeding $17.40 \mu \mathrm{g}$ Chl $a \mathrm{~g}^{-1}$ sed DW under $0.5 \mathrm{~cm}$ bsf (Table 1).

\subsection{The distribution of fauna abundances}

367 The abundance of six meiofaunal groups was recorded: nematods, copepods, ostracods, small 368 gastropods, small bivalves and foraminifera (Supp info Fig S5). The most abundant were the nematods (maximum abundance $=1060$ ind $\mathrm{cm}^{-3}$ ) and foraminifera (maximum abundance $=57$ ind $\mathrm{cm}^{-3}$ ). The abundances of groups investigated decreased with depth increase (Supp info Fig. S5). Higher abundances were recorded in July except for copepods and ostracods. Additionally,

372 the macrozoobenthic grazer, Peringia ulvae (Pennant, 1777) present at the surface of the

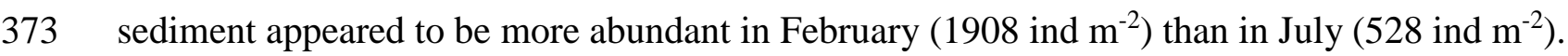

\subsection{Factors influencing prokaryotic activities and densities} silicate concentrations and $\mathrm{M}$ table: juvenile gastropods) had a significant effect on prokaryotic activity and abundance (Supp info Table S4). The environmental variables (E table) explained $14.25 \%$ of the variance of distribution of the prokaryote-related variables without the component variations shared with the meiofauna abundance ( $\mathrm{M}$ table). While meiofaunal 380 abundances explained $5.72 \%$ of the variation of prokaryotic variables. Collectively, phosphate

381 and silicate concentrations, salinity, and abundances of little gastropods explained 59\% of the prokaryotic abundances and activity variations (Figure 3). 


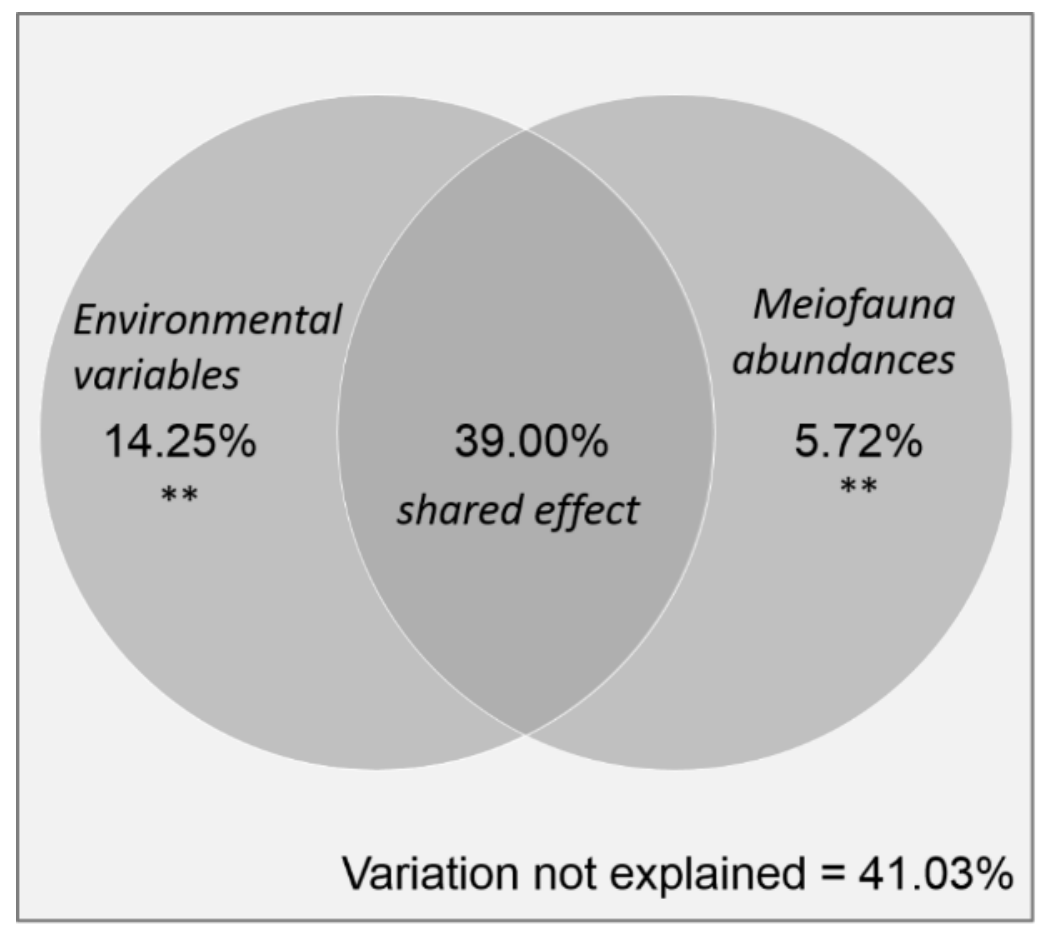

Figure 3. Venn diagram based on a variation partitioning from prokaryotic variables

385 (i.e., prokaryotic abundance; thymidine incorporation; aminopeptidase activity; and beta386 glucosidase activity). The external square represents the whole variation of the prokaryotic 387 table. Each circle represents the explanatory tables and values are the part of the variation 388 explained by each explanatory table. The variables used in the analysis was previously selected 389 by forward selection and final tables included: Environmental variable table: Salinity, $\mathrm{PO}_{4}{ }^{3-}$ 390 concentrations, and silicate concentrations; and meiofauna table: abundances of juvenile 391 gastropods. Statistically significant pure fraction of variation of prokaryotes communities are 392 presented as: $<0.01 * *$ (ANOVA like permutation test, 9999 permutations) and details are given 393 in Supp info Table S4. 


\section{Discussion}

The muddy sediments in Marennes-Oléron Bay support high microbial activities and 396 production rates as is typical for fine-grained sediments (Böer, 2008; Llobet-Brossa et al., 397 1998). This study shows depth gradients of prokaryotic abundances and activities in the top 10$398 \mathrm{~cm}$ of these coastal mudflats based on the analyses of depth layers chosen to characterize 399 centimetre-scale processes. The stratification was particularly pronounced for the sampling in 400 July and this appeared to be related to depth variation of abiotic and biotic environmental 401 variables. Using the set of these environmental variables in the different depth layers, we have studied how they could statistically explain the differences of prokaryotic abundances and activities in the sediment. However, we had to exclude grain size and oxygen. The former

404 showed hardly any variation with depth, while the latter is known to show mm-scale variation 405 close to the surface that was not adequately measured in this study. Nevertheless, a sufficiently 406 large panel of biotic and abiotic variables were available for disentangling the contributions of these environmental variables for driving prokaryotic abundances and activities.

\subsection{Relative impact of environmental variables and meiofauna: the main driving factors}

A forward selection identified that prokaryotic abundances and activities were 410 significantly influenced by salinity, phosphate and silicate concentrations as well as juvenile 411 gasteropod abundances. Above all, the resulting variation partition, underlined that the 412 interaction among physicochemical variables and meiofaunal abundance is high and has a 413 significant impact on prokaryotic abundances and activities (Figure 3). While the gasteropod 414 juveniles are not abundant in this study, their distribution significantly affects the prokaryotic415 related variables and is strongly related to physicochemical variables (i.e., large part of variance 416 explanation shared with environmental table). 
Nitrites or nitrates are more often identified as forcing factors for prokaryotic communities in sediments (Böer et al., 2009), however, in the current study, the use of variation partition shows that others inorganic nutrients such as silicates and phosphates significantly influenced the prokaryotic activities and abundances. Interestingly, the phosphate concentrations appeared to limit the prokaryotic activities (e.g., thymidine incorporation, aminopeptidase and beta-glucosidase activities) more than nitrogen-related nutrients in bottom layers in July and in surface in February (i.e. DIN:PO ${ }^{3-}$ ratio>16; Supp info Figure S2). In a previous study, Pascal et al. (2009) showed that only $6 \%$ of the total bacterial biomass was controlled by consumers in the first $1 \mathrm{~cm}$ of the sediment surface, suggesting a major effect of resources in the Marennes-Oléron mudflat. Our statistical results suggest that the activities and abundances of benthic prokaryotes in the first $10 \mathrm{~cm}$ of sediment were more influenced by physicochemical properties of the sediment (i.e., inorganic nutrients and salinity) rather than by predation pressure by meiofauna (Supp info Table S4). The variation partitioning 430 that we propose statistically identifies that bottom-up control (represented by physicochemical 431 variables) had stronger influence on prokaryotic activities than top-down control by meiofauna 432 and that the shared interactions between the two trophic controls are of major importance. In 433 the current study, it appears that physicochemical properties of the sediment that varied with 434 depth strongly stratified the biotic communities. The high part of variation explained by the two 435 trophic controls could reflects this influence of physicochemical variables on both prokaryotic 436 activities and abundances and meiofauna abundances. However, it could also be due to the fact 437 that meiofauna could slightly modifies the vertical stratification of organic matter, inorganic 438 nutrient or EPS composition. Other proxies can be used to identify factors that drive microbial 439 communities. For example, Pace \& Cole (1994) proposed that a strong positive correlation 440 between prokaryotic biomass and production rates indicates bottom-up control. This relation 
can thus be successfully applied to understand the relationships in benthic microbial ecology,

442 although other factors such as organic matter should also be considered.

\subsection{Two horizons, two different stories}

The principal component analysis followed by hierarchical clustering based on physicochemical variables confirmed a vertical zonation mainly described by organic matter composition (i.e., the TOC:TN ratio), $\mathrm{pH}$ and salinity (Figure 1). Collectively, our results showed that the upper $10 \mathrm{~cm}$ of the sediment was divided into two clearly different horizons with thickness varying between the samplings in July and February. The surface horizon, separated from the bottom one by a transition layer is thicker in February $(2 \mathrm{~cm})$ than in July (1 $\mathrm{cm})$. The position of the transition zone proposed here was therefore dependent on the thickness of the sampling layers in our study and was expected to fluctuate from $1 \mathrm{~cm}$ to $3.5 \mathrm{~cm} \mathrm{bsf}$ (middle of our sampling layer).

The biotic and abiotic variables in the surface horizon differed between the two sampling dates. In July, prokaryotic and environmental variables (e.g., prokaryotic abundance, thymidine incorporation, aminopeptidase activity, EPS-carbohydrates and salinity) were high compared to February (Table 1 and Figure 2). For example, in July, aminopeptidase activity was particularly high compared to other studies (as reviewed by Danovaro et al. (2002)) but comparable with aminopeptidase activities recorded in the Balearic Sea (Tholosan et al., 1999). Thymidine incorporation, used as a proxy of benthic bacterial production, drastically increased 460 with an increase of $10^{\circ} \mathrm{C}$ (i.e., high $\mathrm{Q}_{10}$ value). On the basis of our results (Figure 2), we 461 hypothesized that in February, in the surface horizon (0-2 cm bsf), the prokaryotic communities 462 showing low metabolic activities were not able to sustain growth as a large part of their 463 metabolic energy was used for maintenance. In contrast, in July, as a result of higher temperature, the high densities and high metabolic rates of prokaryotes seemed to be related to 
surface horizon are strongly influenced by external parameters (e.g., light exposure, 467 resuspension and tidal cycle) and microphytobenthic activity. Although algal biomass (i.e., as measured by chlorophyll $a$ concentration) was in the same range for both sampling dates, the high microphytobenthic primary production in July (gross primary production: $6.0 \pm 1.7 \mathrm{mg} \mathrm{C}$ $470 \mathrm{~h}^{-1} \mathrm{~m}^{-2}, \mathrm{CO}_{2}$ fluxes in benthic chambers measurement method, pers. comm. from J. Lavaud) 471 had probably enhanced the bacterial production in the sediment top layer $(0-0.5 \mathrm{~cm}$ bsf $)$. This 472 source of labile carbon may be quickly transferred to the bacterial compartment as shown 473 previously in sandy sediments (Cook et al., 2007) and intertidal flats (Middelburg et al., 2000). Moreover, large amounts of EPS-carbohydrates were recorded in July compared to February and these EPS may be produced by epipelic diatoms in response to nutrient limitation or photoprotection (Smith and Underwood, 2000, 1998). Together, the high EPS-carbohydrates concentrations, the low nutrient concentrations, and the DIN:PO $4^{3-}$ ratio below the Redfield value (Redfield, 1958), suggested a nitrogen limitation for benthic micro-organisms in surface 479 in July.

While EPS-carbohydrates were dominant in July, EPS-proteins clearly increased in 481 February (as shown by the shift of the ratio EPS-carbohydrates/EPS-proteins, Supp info Figure 482 S3). At this date, both prokaryotic density and thymidine incorporation were low in the top 483 horizon (0-2 $\mathrm{cm}$ bsf, Figure 2) and this was not only due to the low sediment temperature because higher bacterial production occurred deeper in the sediment despite a similar temperature. A study in Marennes-Oléron mudflat (Orvain et al., 2014b) shows that a higher proportion of EPS-proteins coincided with mass erosion events and higher abundance of the macrozoobenthic grazer, Peringia ulvae (Pennant, 1777). These macrozoobenthic grazers may disturb the sediment stability by grazing on biofilm and EPS-proteins may potentially originated from shell mucus (Orvain et al., 2014b). Based on these features and on our results, 490 it may be possible that the highest abundance of Peringia ulvae (Pennant, 1777) recorded in 
491 February provoked a high predation pressure (i.e., predation pressure: $1.72 \mathrm{mg} \mathrm{C} \mathrm{h}^{-1}$, calculated 492 according to Pascal et al. (2009)) and an increase of EPS-proteins, hence inducing mass erosion 493 of the sediment. This erosion is associated with the release of diatoms and prokaryotes into the 494 water column (Guizien et al., 2014; Montanié et al., 2014; Shimeta et al., 2002) and may 495 therefore impact the surface of sediment in February by a decrease of prokaryotic density and 496 bacterial production. Finally, in our study, even if mass erosion of the sediment surface might 497 have occurred at seeing the sea state (Suppl. Info, Table S2) and the wind speeds (data not 498 shown), prokaryotic abundance could be lower because of the grazing of Peringia ulvae 499 (Pennant, 1777) or by viral lysis that has been reported to be responsible for the loss of $40 \%$ of 500 bacterial production in Marennes-Oléron mudflat (Saint-Béat et al., 2013). These results 501 suggesting a mass erosion event that occurred in February are consistent with a thicker surface 502 horizon (from 0 to $2 \mathrm{~cm}$ bsf) compared to the one in July. In the bottom horizon, between 1 or $2 \mathrm{~cm}$ bsf (in July and February, respectively) and 10 cm bsf, all biotic and physicochemical gradients showed little variation with depth. For both sampling dates, the thymidine incorporation used as a proxy of bacterial production was similar 506 below $2 \mathrm{~cm}$ depth despite high environmental differences. Indeed, temperature, salinity, and 507 the EPS-carbohydrates strongly decreased from July to February, and nutrient concentrations 508 also changed - specifically, phosphate and ammonium concentrations increased (Supp info 509 Figure S2). While this bacterial production was clearly lower in this bottom horizon compared 510 to the surface one we probably underestimated thymidine uptake in the anoxic layers because 511 the experiments were not performed under anoxic conditions while microorganisms may be 512 partially or strictly anaerobes. Despite this potential underestimation, bacterial communities were able to maintain the same production level between 2 and $10 \mathrm{~cm}$ bsf in both sampling 514 dates, suggesting that the system may potentially contain a low and stable microbial bulk 515 activity in this horizon throughout the year independently of environmental changes. 
The boundary layer may represent a transition zone between the surface horizon largely influenced by external parameters and the bottom horizon corresponding to reduced sediment.

The current study proposes that the transition zone should represent the limit of influence of

weather conditions on sediment physicochemical properties and thus on prokaryotic activities

521 in the intertidal mudflat. The depth of this layer was expected to fluctuate weakly over the

522 seasons and among the low tide period. Notably, storms can destroy the vertical structure deeper

523 than the external parameter-influenced zone. Nevertheless, except during these rare but strong

524 events, the depth of this surface layer can be considered specific to intertidal muddy sediments.

525 Indeed, sandy sediments are generally permeable and allow advective fluxes of water through

526 the interstitial spaces (Musat et al., 2006) and thus exhibit a different depth profile compared to

527 muddy sediments. Except for transient storms, the transition layer is thus located at $1-3.5 \mathrm{~cm}$

528 depth in intertidal muddy sediments.

Whether this transition zone represents an environmental ecotone or ecocline can be

530 discussed. These two terms have been largely used in ecology to characterize boundary zones

531 where gradients occur, but their definitions and how to use them are still unclear (Erdôs et al.,

532 2011). Nevertheless, many authors agree that the term environmental ecotone defines a gradient

533 between two adjacent habitats characterized by rather abrupt changes and that it comprises

534 habitats that should be very specific for certain species (Attrill and Rundle, 2002; Erdôs et al.,

535 2011; van der Maarel, 1990; Whittaker, 1967). In contrast, an environmental ecocline stands

536 for more gradual changes that may result from mixing of the two communities from the

537 neighboring habitats (Attrill and Rundle, 2002; Erdôs et al., 2011; van der Maarel, 1990;

538 Whittaker, 1967). In the present study, the transition zone corresponded to a gradient zone at a

$539 \mathrm{~cm}$ scale which we characterized by a gradual change of environmental variables such as

540 porosity or EPS ratios and a gradual change of microbial communities (e.g., algal biomass, 
541 enzymatic activities and prokaryotic abundance). Hence, following these definitions and our

542 findings, we should rather consider the identified transition zone as an environmental ecoclinal 543 boundary (Erdôs et al., 2011).

\subsection{Conclusion}

The current study provided detailed snapshots of the depth gradients of prokaryotic

546 abundances and process rates at two sampling dates at low tide. The detailed stratification

547 pattern using a large ensemble of variables and different multivariate analyses allowed us to

548 decipher some of the major factors driving the densities and activities of microbial populations

549 in intertidal sediments. Thus, we succeeded in statistically explaining a large part of the

550 prokaryotic activity distributions by the environmental variables (i.e., salinity and nutrients),

551 and to a lesser extent by consumers (meiofauna), suggesting that bottom-up control was more

552 important than top-down control. In general we observed that the top $10 \mathrm{~cm}$ of these muddy

553 sediments comprise two clearly different depth horizons that are separated by a transition zone.

554 Thus we identified a surface horizon, which appears variable in thickness between sampling

555 dates and where prokaryotic activities and densities are highly impacted by microphytobenthic

556 activities and physicochemical variables and, a deeper and more stable bottom horizon. The

557 transition appears to be gradual corresponding to an environmental ecocline rather than an 558 ecotone.

559 Nevertheless, one part of this distribution remained statistically unexplained (41\% of 560 the variation is estimated to be unresolved by the chosen variables in the variation partitioning) 561 and further studies are needed to explore 1) other abiotic variables such as sulfate, iron oxide 562 or manganese oxide concentration, 2) prokaryotic activity and production dynamics throughout 563 the low tide period, and 3) other prokaryotic indices such as diversity or functional genes. 


\section{Figure captions}

Figure 1. Principal component analysis (PCA) ordination calculated using 8 physicochemical variables for a and c) 15 samples in July and b and d) 15 samples in February. a and b) Ordination of the variables and correlation circle. $b$ and d) Position of the observations in the ordination; tree calculated hierarchical classification on principle components and the different clusters evaluated using 10000 iterations . T: temperature; S: salinity; Prot: total protein content; EPS.CB: colloidal EPS/bound EPS ratio; EPS.CP: EPS-carbohydrates/EPS-protein ratio; DIN.P: DIN:PO ${ }^{3-}$ ratio; TOC:TN: ratio of total organic carbon (TOC) and total nitrogen (TN). PCA and hierarchical classification were performed using "FactoMineR" package (Husson et al., 2013).

Figure 2. Prokaryotic abundances, production and activities along a vertical depth gradient below the sediment surface (bsf). All points represent the middle of each layer. The coefficient of variation is displayed as bubble size. Black bubbles represent values for July 5, 2012, and gray bubbles represent values for February 11, 2013.

Figure 3. Venn diagram based on a variation partitioning from prokaryotic variables (i.e., prokaryotic abundance; thymidine incorporation; aminopeptidase activity; and betaglucosidase activity). The external square represents the whole variation of the prokaryotic table. Each circle represents the explanatory tables and values are the part of the variation explained by each explanatory table. The variables used in the analysis was previously selected by forward selection and final tables included: Environmental variable table: Salinity, $\mathrm{PO}_{4}{ }^{3-}$ content, and silicate content; and meiofauna table: abundances of juvenile gastropods. Statistically significant pure fraction of variation of prokaryotes communities are presented as: $<0.01 * *$ (ANOVA like permutation test, 9999 permutations) and details are given in Supp info Table S4. 


\section{$588 \quad 8$ Table caption}

Table 1. Average of each environmental variables and algal biomass ( \pm SE) along

590 sediment depths. Two-way ANOVA reveals always significant differences between the two

591 sampling dates for all variables $(p<0.05)$, letters in bold font indicate Tukey's post hoc test for 592 each sampling date.

593 


\section{Acknowledgments}

This research was supported by a $\mathrm{PhD}$ grant (for Céline Lavergne) from the Charente

596 Maritime Department and by the French national program CPER 2006-2014 (Contrat Projet 597 Etat Région) of Charente Maritime, the French national program EC2CO (CAPABIOC, 2012598 2014), and the CNRS (French National Center for Scientific Research). We acknowledge the 599 different analytical facilities in LIENSs laboratory: 'Cytometry and imaging Facility', 600 'Radioactive Facility', 'Microbiological Facility', and 'Logistic, field Facility'. We are grateful 601 to K. Guizien and S. Lucas (LECOB, Banyuls s/ Mer, France), the LPO (French Bird Life 602 International organization) and D. Prevostat (Aeroglisseurs services) for their help in the field 603 and expertise. We also thank M. Le Goff (LEMAR, Plouzané, France) and PACHIDERM 604 analytical platform (Plouzané, France), V. Meleder (MMS, Nantes, France) and the analytic 605 platform of Geolittomer (UMR LETG, Nantes, France) for their expertise. Authors are grateful 606 to J. Lavaud and A. Barnett, I. Lanneluc, S. Sablé, I. Doghri, L. Beaugeard and J. Jourde. 607 Authors are also grateful to E. Desoche, A. Dupuy, C. Dussud and C. Le Kieffre. 


\section{References}

609

610

611

612

613

614

615

616

617

618

619

620

621

622

623

624

625

626

627

628

629

630

631

632

633

634

635

636

637

638

639

640

641

642

643

644

645

646

647

648

Admiraal, W., 1984. The ecology of estuarine sediment inhabiting diatoms. Prog. Phycol. Res. 3, 269-314.

Agogué, H., Mallet, C., Orvain, F., De Crignis, M., Mornet, F., Dupuy, C., 2014. Bacterial dynamics in a microphytobenthic biofilm: A tidal mesocosm approach. J. Sea Res. 92, 3645. doi:10.1016/j.seares.2014.03.003

Aminot, A., Kérouel, R., 2007. Dosage automatique des nutriments dans les eaux marines: méthodes en flux continu. Ifremer.

Attrill, M.J., Rundle, S.D., 2002. Ecotone or Ecocline: Ecological Boundaries in Estuaries. Estuar. Coast. Shelf Sci. 55, 929-936. doi:10.1006/ecss.2002.1036

Bertics, V.J., Ziebis, W., 2010. Bioturbation and the role of microniches for sulfate reduction in coastal marine sediments. Environ. Microbiol. 12, 3022-3034. doi:10.1111/j.14622920.2010.02279.x

Bertics, V.J., Ziebis, W., 2009. Biodiversity of benthic microbial communities in bioturbated coastal sediments is controlled by geochemical microniches. ISME J 3, 1269-1285.

Blott, S.J., Pye, K., 2001. GRADISTAT: a grain size distribution and statistics package for the analysis of unconsolidated sediments. Earth Surf. Process. Landforms 26, 1237-1248. doi:10.1002/esp.261

Böer, S., 2008. Investigation of the distribution and activity of benthic microorganisms in coastal habitats. Bremen University.

Böer, S., Hedtkamp, S.I., van Beusekom, J.E., Fuhrman, J.A., Boetius, A., Ramette, A., 2009. Time- and sediment depth-related variations in bacterial diversity and community structure in subtidal sands. ISME J 3, 780-791. doi:10.1038/ismej.2009.29

Boetius, A., 1995. Microbial hydrolytic enzyme activities in deep-sea sediments. Helgoländer Meeresuntersuchungen 49, 177-187.

Boetius, A., Lochte, K., 1996. Effect of organic enrichments on hydrolytic potentials and growth of bacteria in deep-sea sediments. Mar. Ecol. Prog. Ser. 140, 239-250. doi:10.3354/meps 140239

Borcard, D., Legendre, P., Drapeau, P., 1992. Partialling out the Spatial Component of Ecological Variation. Ecology 73, 1045-1055. doi:10.2307/1940179

Cook, P.L.M., Veuger, B., Böer, S., Middelburg, J.J., 2007. Effect of nutrient availability on carbon and nitrogen incorporation and flows through benthic algae and bacteria in nearshore sandy sediment. Aquat. Microb. Ecol. 49, 165-180. doi:10.3354/ame01142

Danovaro, R., Manini, E., Fabiano, M., 2002. Exoenzymatic activity and organic matter composition in sediments of the Northern Adriatic Sea: response to a river plume. Microb. Ecol. 44, 235-251. doi:10.1007/s00248-002-1023-2

De Mesel, I., Derycke, S., Moens, T., Van der Gucht, K., Vincx, M., Swings, J., 2004. Topdown impact of bacterivorous nematodes on the bacterial community structure: a microcosm study. Environ. Microbiol. 6, 733-744. doi:10.1111/j.14622920.2004.00610.x

Decho, A.W., 2000. Microbial biofilms in intertidal systems: an overview. Cont. Shelf Res. 20, 
Dray, S., Legendre, P., Blanchet, F.G., 2013. packfor: Forward Selection with permutation (Canoco p.46). R Packag. version 0.0-8/r109.

Dubois, M., Gilles, K.A., Hamilton, J.K., Rebers, P.A., Smith, F., 1956. Colorimetric method for determination of sugars and related substances. Anal. Chem. 28, 350-356.

Dupuy, C., Mallet, C., Guizien, K., Montanié, H., Bréret, M., Mornet, F., Fontaine, C., Nérot, C., Orvain, F., 2014. Sequential resuspension of biofilm components (viruses, prokaryotes and protists) as measured by erodimetry experiments in the Brouage mudflat (French Atlantic coast). J. Sea Res. 92, 56-65. doi:10.1016/j.seares.2013.12.002

Erdôs, L., Zalatnai, M., Morschhauser, T., Bátori, Z., Körmöczi, L., 2011. On the terms related to spatial ecological gradients and boundaries. Acta Biol. Szeged. 55, 279-287.

Fabiano, M., Danovaro, R., 1998. Enzymatic activity, bacterial distribution, and organic matter composition in sediments of the Ross Sea (Antarctica). Appl. Environ. Microbiol. 64, 3838-3845.

Folk, R.L., Ward, W.C., 1957. Brazos River bar (Texas); a study in the significance of grain size parameters. J. Sediment. Petrol. 27, 3-26.

Fuhrman, J.A., Hagström, ̊̊., 2008. Bacterial and archaeal community structure and its patterns, in: Microbial Ecology of the Oceans. John Wiley \& Sons, Inc., pp. 45-90. doi:10.1002/9780470281840.ch3

Garet, M.J., Moriarty, D.J.W., 1996. Acid extraction of tritium label from bacterial DNA in clay sediment. J. Microbiol. Methods 25, 1-4. doi:10.1016/0167-7012(95)00071-2

Gilbertson, W.W., Solan, M., Prosser, J.I., 2012. Differential effects of microorganisminvertebrate interactions on benthic nitrogen cycling. FEMS Microbiol. Ecol. 82, 11-22. doi:10.1111/j.1574-6941.2012.01400.x

Guizien, K., Dupuy, C., Ory, P., Montanié, H., Hartmann, H., Chatelain, M., Karpytchev, M., 2014. Microorganism dynamics during a rising tide: Disentangling effects of resuspension and mixing with offshore waters above an intertidal mudflat. J. Mar. Syst. 129, 178-188. doi:10.1016/j.jmarsys.2013.05.010

Hubas, C., Lamy, D., Artigas, L., Davoult, D., 2007. Seasonal variability of intertidal bacterial metabolism and growth efficiency in an exposed sandy beach during low tide. Mar. Biol. 151, 41-52. doi:10.1007/s00227-006-0446-6

Husson, F., Josse, J., Le, S., Mazet, J., 2013. FactoMineR: multivariate exploratory data analysis and data mining with $\mathrm{R}$.

Jones, C., Lawton, J., Shachak, M., 1996. Organisms as Ecosystem Engineers, in: Ecosystem Management. Springer New York, pp. 130-147. doi:10.1007/978-1-4612-4018-1_14

Kristensen, E., 2000. Organic matter diagenesis at the oxic/anoxic interfacein coastal marine sediments, with emphasis on the role of burrowing animals. Hydrobiologia 1-24. doi:10.1023/A:1003980226194

Lavergne, C., Beaugeard, L., Dupuy, C., Courties, C., Agogué, H., 2014. An efficient and rapid method for the enumeration of heterotrophic prokaryotes in coastal sediments by flow cytometry. J. Microbiol. Methods 105, 31-38. doi:10.1016/j.mimet.2014.07.002

Legendre, P., Legrendre, L., 1998. Numerical ecology. Developments in environmental modelling. Elsevier Science \& Technology. 
Llobet-Brossa, E., Rosselló-Mora, R., Amann, R., 1998. Microbial community composition of Wadden Sea sediments as revealed by fluorescence in situ hybridization. Appl. Environ. Microbiol. 64, 2691-2696.

Lomas, M.W., Glibert, P.M., Shiah, F.-K., Smith, E.M., 2002. Microbial processes and temperature in Chesapeake Bay: current relationships and potential impacts of regional warming. Glob. Chang. Biol. 8, 51-70. doi:10.1046/j.1365-2486.2002.00454.x

Lorenzen, C.J., 1966. A method for the continuous measurement of in vivo chlorophyll concentration. Deep. Res. Oceanogr. Abstr. 13, 223-227.

McKew, B.A., Dumbrell, A.J., Taylor, J.D., McGenity, T.J., Underwood, G.J.C., 2013. Differences between aerobic and anaerobic degradation of microphytobenthic biofilmderived organic matter within intertidal sediments. FEMS Microbiol. Ecol. 84, 495-509. doi:10.1111/1574-6941.12077

Middelburg, J.J., Barranguet, C., Boschker, H.T.S., Herman, P.M.J., Moens, T., Heip, C.H.R., 2000. The fate of intertidal microphytobenthos carbon: An in situ13C-labeling study. Limnol. Oceanogr. 45, 1224-1234. doi:10.4319/lo.2000.45.6.1224

Montanié, H., Ory, P., Orvain, F., Delmas, D., Dupuy, C., Hartmann, H.J., 2014. Microbial interactions in marine water amended by eroded benthic biofilm: A case study from an intertidal mudflat. J. Sea Res. 92, 74-85. doi:10.1016/j.seares.2013.11.011

Musat, N., Werner, U., Knittel, K., Kolb, S., Dodenhof, T., van Beusekom, J.E.E., de Beer, D., Dubilier, N., Amann, R., 2006. Microbial community structure of sandy intertidal sediments in the North Sea, Sylt-Rømø Basin, Wadden Sea. Syst. Appl. Microbiol. 29, 333-348. doi:10.1016/j.syapm.2005.12.006

Nemenyi, P., 1963. Distribution-free Multiple Comparisons. Princeton University.

Oksanen, J., Blanchet, F.G., Kindt, R., Legendre, P., Minchin, P.R., O’Hara, R.B., Simpson, G.L., Solymos, P., Steven, M.H.H., Wagner, H., 2013. vegan: Community Ecology Package. R Packag. version 2.0-7.

Orvain, F., De Crignis, M., Guizien, K., Lefebvre, S., Mallet, C., Takahashi, E., Dupuy, C., 2014a. Tidal and seasonal effects on the short-term temporal patterns of bacteria, microphytobenthos and exopolymers in natural intertidal biofilms (Brouage, France). J. Sea Res. 92, 6-18. doi:10.1016/j.seares.2014.02.018

Orvain, F., Guizien, K., Lefebvre, S., Bréret, M., Dupuy, C., 2014b. Relevance of macrozoobenthic grazers to understand the dynamic behaviour of sediment erodibility and microphytobenthos resuspension in sunny summer conditions. J. Sea Res. 92, 46-55. doi:10.1016/j.seares.2014.03.004

Pace, M.L., Cole, J.J., 1994. Comparative and experimental approaches to top-down and bottom-up regulation of bacteria. Microb. Ecol. 28, 181-193. doi:10.1007/bf00166807

Pascal, P.Y., Dupuy, C., Richard, P., Mallet, C., Arminot du Châtelet, E., Niquil, N., 2009. Seasonal variation in consumption of benthic bacteria by meio- and macrofauna in an intertidal mudflat. Limnol. Oceanogr. 54, 1048-1059. doi:10.4319/lo.2009.54.4.1048

Pohlert, T., 2014. The Pairwise Multiple Comparison of Mean Ranks Package (PMCMR). R Packag.

R Core Team, 2013. R: a language and environment for statistical computing.

Ramette, A., 2007. Multivariate analyses in microbial ecology. FEMS Microbiol. Ecol. 62, 
Ramette, A., Tiedje, J., 2007. Biogeography: an emerging cornerstone for understanding prokaryotic diversity, ecology, and evolution. Microb. Ecol. 53, 197-207. doi:10.1007/s00248-005-5010-2

Redfield, A.C., 1958. The biological control of chemical factors in the environment. Am. Sci. 46, 205-221.

Sachs, L., 1997. Angewandte Statistik. Springer Berlin, Berlin, Heidelberg. doi:10.1007/9783-662-05746-9

Saint-Béat, B., Dupuy, C., Bocher, P., Chalumeau, J., De Crignis, M., Fontaine, C., Guizien, K., Lavaud, J., Lefebvre, S., Montanié, H., Mouget, J.-L., Orvain, F., Pascal, P.-Y., Quaintenne, G., Radenac, G., Richard, P., Robin, F., Vézina, A.F., Niquil, N., 2013. Key features of intertidal food webs that support migratory shorebirds. PLoS One 8, e76739. doi:10.1371/journal.pone.0076739

Seeberg-Elverfeldt, J., Schlüter, M., Feseker, T., Kölling, M., 2005. Rhizon sampling of porewaters near the sediment-water interface of aquatic systems. Limnol. Oceanogr. Methods 3, 361-371. doi:10.4319/lom.2005.3.361

Shimeta, J., Amos, C.L., Beaulieu, S.E., Ashiru, O.M., 2002. Sequential resuspension of protists by accelerating tidal flow: Implications for community structure in the benthic boundary layer. Limnol. Oceanogr. 47, 1152-1164. doi:10.4319/lo.2002.47.4.1152

Smith, D.J., Underwood, G.J.C., 2000. The production of extracellular carbohydrates by estuarine benthic diatoms: the effects of growth phase and light and dark treatment. J. Phycol. 36, 321-333. doi:10.1046/j.1529-8817.2000.99148.x

Smith, D.J., Underwood, G.J.C., 1998. Exopolymer production by intertidal epipelic diatoms. Limnol. Oceanogr. 43, 1578-1591. doi:10.4319/lo.1998.43.7.1578

Smith, P.K., Krohn, R.I., Hermanson, G.T., Mallia, A.K., Gartner, F.H., Provenzano, M.D., Fujimoto, E.K., Goeke, N.M., Olson, B.J., Klenk, D.C., 1985. Measurement of protein using bicinchoninic acid. Anal. Biochem. 150, 76-85. doi:10.1016/0003-2697(85)904427

Soetaert, K., Herman, P.M.J., Middelburg, J.J., 1996. Dynamic response of deep-sea sediments to seasonal variations: A model. Limnol. Ocean. 41, 1651-1668.

Strickland, J.D.H., Parsons, T.R.A., 1972. Practical handbook of sea water analysis. Bull. Fish. Res. Board Canada 167, 207-211.

Takahashi, E., Ledauphin, J., Goux, D., Orvain, F., 2009. Optimising extraction of extracellular polymeric substances (EPS) from benthic diatoms: comparison of the efficiency of six EPS extraction methods. Mar. Freshw. Res. 60, 1201-1210. doi:10.1071/MF08258

Tholosan, O., Lamy, F., Garcin, J., Polychronaki, T., Bianchi, A., 1999. Biphasic Extracellular Proteolytic Enzyme Activity in Benthic Water and Sediment in the Northwestern Mediterranean Sea. Appl. Environ. Microbiol. 65, 1619-1626.

Underwood, G.J.C., Kromkamp, J., 1999. Primary production by phytoplankton and microphytobenthos in estuaries, in: Nedwell, D.B., Raffaelli, D.G. (Eds.), Advances in Ecological Research. Academic Press, pp. 93-153. doi:http://dx.doi.org/10.1016/S00652504(08)60192-0

Van Colen, C., Underwood, G.J.C., Serôdio, J., Paterson, D.M., 2014. Ecology of intertidal 
microbial biofilms: Mechanisms, patterns and future research needs. J. Sea Res. 92, 2-5. doi:10.1016/j.seares.2014.07.003

van der Maarel, E., 1990. Ecotones and ecoclines are different. J. Veg. Sci. 1, 135-138. doi: $10.2307 / 3236065$

Volis, S., Dorman, M., Blecher, M., Sapir, Y., Burdeniy, L., 2011. Variation partitioning in canonical ordination reveals no effect of soil but an effect of co-occurring species on translocation success in Iris atrofusca. J. Appl. Ecol. 48, 265-273. doi:10.1111/j.13652664.2010.01898.x

Whitman, W.B., Coleman, D.C., Wiebe, W.J., 1998. Prokaryotes: The unseen majority. Proc. Natl. Acad. Sci. 95, 6578-6583.

Whittaker, R.H., 1967. Gradient analysis of vegetation. Biol. Rev. 42, 207-264. doi:10.1111/j.1469-185X.1967.tb01419.x

Zinger, L., Amaral-Zettler, L.A., Fuhrman, J.A., Horner-Devine, M.C., Huse, S.M., Welch, D.B.M., Martiny, J.B.H., Sogin, M., Boetius, A., Ramette, A., 2011. Global patterns of bacterial beta-diversity in seafloor and seawater ecosystems. PLoS One 6, e24570. doi:10.1371/journal.pone.0024570 